\title{
SISTIM PEMILIHAN UMUM
}

\author{
Nama : Larasati Permata Putri \\ Email $\quad$ : Yayaspuput2105@gmail.com \\ No Bp : 2010003600070 \\ Perguruan Tinggi : Universitas Eka Sakti
}

\section{A. PENDAHULUAN}

Di kebanyakan negara demokrasi, pemilihan umum dianggap lambang, sekaligus tolak ukur dari sebuah demokrasi. Hasil pemilihan umum yang diselenggarakan dalam suasana keterbukaan dengan kebebasan berpendapat dan kebebasan berserikat, dianggap mencerminkan walaupun tidak begitu akurat, partisipasi dan kebebasan masyarakat. Sekalipun demikian, disadari bahwa pemilihan umum (PEMILU) tidak merupakan satu-satunya tolak ukur dan perlu dilengkapi dengan pengukuran beberapa kegiatan lain yang lebih bersifat berkesinambungan, seperti partisipasi dalam kegiatan partai, lobbying, dan sebagainya.

Di banyak negara berkembang beberapa kebebasan seperti yang dikenal di dunia barat kurang diindahkan. Seperti Indonesia, perkembangan demokrasi di Indonesia telah mengalami pasang surut. Selama 67 tahun berdirinya Republik Indonesia ternyata masalah pokok yang kita hadapi adalah bagaimana dalam masyarakat yang beraneka ragam pola budayanya dapat mempertinggi tingkat kehidupan ekonomi disamping membina suatu kehidupan sosial dan politik yang demokratis.pada pokok masalah ini berkisar pada penyusunan suatu sistem politik dimana kepemimpinaan cukup kuat untuk melaksanakan pembangunan ekonomi serta nation building, dengan partisipasi rakyat seraya menghindarkan timbulnya diktator.

Pemilihan umum juga menunjukkan seberapa besar partisipasi politik masyarakat, terutama di negara berkembang. Kebanyakan negara ini ingin cepat mengadakan pembangunan untuk mengejar keterbelakangannya, karena dianggap bahwa berhasil-tidaknya pembangunan banyak bergantung pada partisipasi rakyat. Ikut sertanya masyarakat akan membantu penanganan

masalah-masalah yang ditimbulkan oleh perbedaan-perbedaan etnis, budaya, status sosial, ekonomi, budaya, dan sebagainya. Integritas nasional, pembentukan identitas nasional, serta loyalitas terhadap negara diharapkan akan ditunjang pertumbuhannya melalui partisipasi politik. 
Di beberapa negara berkembang partisipasi yang bersifat otonom, artinya lahir dari mereka sendiri, masih terbatas. Di beberapa negara yang rakyatnya apatis, pemerintah menghadapi masalah bagaimana meningkatkan partisipasi itu, sebab jika partisipasi mengalami jalan buntu , dapat terjadi dua hal yaitu "anomi” atau justru " revolusi”. Maka melalui pemilihan umum yang sering didefenisikan sebagai " pesta kedaulatan rakyat", masyarakat dapat secara aktif menyuarakan aspirasi mereka baik itu ikut berpartisipasi dalam kegiatan partai, ataupun “menitipkan" dan "mempercayakan" aspirasi mereka pada salah satu partai peserta PEMILU yang dianggap dapat memenuhi, serta menjalankan aspirasi masyarakat tyang telah dipercayakan pada partai tersebut

\section{B. PEMBAHASAN}

\section{Pemilihan Umum}

Salah satu wujud demokrasi adalah dengan Pemilihan Umum. Dalam kata lain, Pemilu adalah pengejawantahan penting dari "demokrasi prosedural”. Berkaitan dengan ini, Samuel P. Huntington dalam Sahid gatara (2008: 207) menyebutkan bahwa prosedur utama demokrasi adalah pemilihan para pemimpin secara kompetitif oleh rakyat yang bakal mereka pimpin. Selain itu, Pemilu sangat sejalan dengan semangat demokrasi secara subtansi atau "demokrasi subtansial",

yakni demokrasi dalam pengertian pemerintah yang diselenggarakan dari rakyat, oleh rakyat dan untuk rakyat. Artinya, rakyatlah yang memegang kekuasaan tertinggi.

Pemilu adalah lembaga sekaligus prosedur praktik politik untuk mewujudkan kedaulatan rakyat yang memungkinkan terbentuknya sebuah pemerintahan perwakilan (representative government). Secara sederhana, Pemilihan Umum didefinisikan sebagai suatu cara atau sarana untuk menentukan orang-orang yang akan mewakili rakyat dalam menjalankan pemerintahan.

Dalam pemilihan umum, biasanya para kandidat akan melakukan kampanye sebelum pemungutan suara dilakukan selama selang waktu yang telah dientukan. Dalam kampanye tersebut para kandidat akan berusaha menarik perhatian masyarakat secara persuasif, menyatakan visi dan misinya untuk memajukan dan memperjuangkan kesejahteraan rakyat. 


\section{Tujuan Pemilihan Umum}

Tujuan diselenggarkannya Pemilihan Umum adalah untuk memilih wakil rakyat dan wakil daerah untuk membentuk pemerintahan yang demokratis, kuat dan memperoleh dukungan dari rakyat dalam rangka mewujudkan tujuan nasional.

\section{Manfaat Pemilu}

Pemilu dipandang sebagai bentuk paling nyata dari kedaulatan yang berada di tangan rakyat serta wujud paling konkret partisipasi rakyat dalam penyelenggaraan negara. Oleh karena itu,sistem dan penyelenggaraan pemilu selalu menjadi perhatian utama karena melalui penataan, sistem dan kualitas penyelenggaraan pemilu diharapkan dapat benar-benar mewujudkan pemerintahan dari, oleh, dan untuk rakyat.

\section{Sistem Pemilihan Umum}

Dalam ilmu politik dikenal bermacam-macam sistem Pemilihan Umum dengan berbagai variasinya, akan tetapi pada umumnya berkisar pada dua prinsip pokok, yaitu:

\section{a. Sistem Distrk}

Sistem ini merupakan sistem pemilihan umum yang paling tua dan didasarkan atas kesatuan geografis. Setiap kesatuan geografis (yang biasanya disebut distrik karena kecilnya daerah yang diliputi) mempunyai satu wakil dalam dewan perwakilan rakyat. Untuk keperluan itu, negara dibagi dalam sejumlah besar distrik dan jumlah wakil rakyat dalam dewan perwakilan rakyat ditentukan oleh jumlah distrik. Calon yang di dalam satu distrik memperoleh suara terbanyak dikatakan pemenang, sedangkan suara-suara yang ditujukan kepada calon-calon lain dianggap hilang dan tidak diperhitungkan lagi, bagaimanapun kecilnya selisih kekalahannya.

\section{1) Keuntungan Sistem Distrik}

Sistem ini lebih mendorong ke arah integrasi partai-partai politik karena kursi yang diperebutkan dalam setiap distrik pemilihan hanya satu. Hal ini akan mendorong partai-partai 
untuk menyisihkan perbedaan-perbedaan yang ada dan mengadakan kerja sama, sekurangkurangnya menjelang pemilihan umum, antara lain melalui stembus accord.

Fragmentasi partai dan kecenderungan membentuk partai baru dapat dibendung; malahan sistem ini bisa mendorong ke arah penyederhanaan partai secara alami dan tanpa paksaan.

Karena kecilnya distrik, maka wakil yang terpilih dapat dikenal oleh komunitasnya, sehingga hubungan denga konstituen lebih erat. Dengan demikian si wakil akan lebih cenderung untuk memperjuangkan kepentingan distriknya.

Bagi partai besar system ini menguntungkan karena melalui distortion effect dapat meraih suara dari pemilih-pemilih lain, sehingga memperoleh kedudukan mayoritas. Dengan demikian, sedikit banyak partai pemenang dapat mengendalikan parlemen.

Lebih mudah bagi suatu partai untuk mencapai kedudukan mayoritas dalam parlemen, sehingga tidak perlu diadakan koalisi dengan partai lain. hal ini mendukung stabilitas nasional.

Sistem ini sederhana dan mudah untuk diselenggarakan.

\section{2) Kelemahan Sistem Distrik}

System ini kurang memperhatikan kepentingan partai-partai kecil dan golongan minoritas, apalagi jika golongan-golongan ini terpencar dalam berbagai distrik.

Sistem ini kurang representatif dalam arti bahwa partai yang calonnya kalah dalam suatu distrik kehilangan suara yang telah mendukungnya. Hal ini berarti bahwa ada sejumlah suara yang tidak diperhitungkan sama sekali, atau terbuang sia-sia. Dan jika banyak partai mengadu kekuatan, maka jumlah suara yang hilang dapat mencapai jumlah yang besar. Hal ini akan dianggap tidak adil terhadap partai dan golongan yang dirugikan.

Sistem distrik dian ggap kurang efektif dalam masyarakat yang plural karena terbagi dalam kelompok etnis, religius, dan tribal, sehingga menimbulkan anggapan bahwa kebudayaan nasional yang terpadu secara ideologis dan etnis mungkin merupakan prasyarat bagi suksesnya sistem ini. Ada kemungkinan si wakil cenderung untuk lebih memperhatikan kepentingan distrik serta warga distriknya, daripada kepentingan nasional.

\section{b. Sistem Perwakilan Berimbang atau Sistem proporsional}

Sistem ini dianut oleh Indonesia. Pemilu tidaklah langsung memilih calon yang didukungnya, karena para calon ditentukan berdasarkan nomor urut calon-calon dari masingmasing parpol atau organisasi social politik (orsospol). Para pemilih adalah memilih tanda gambar 
atau lambing sustu orsospol. Perhitungan suara untuk menentukan jumlah kursi raihan masingm,asing orsospol, ditentukan melalui pejumlahan suara secara nasional atau penjumlahan pada suatu daerah (provinsi). Masing-masing daerah diberi jatah kursi berdasarkan jumlah penduduk dan kepadatan penduduk di daerah yang bersagkutan.

Banyak atau sedikitnya kursi yang diraih adalah ditentukan oleh jumlah suara yang diraih masingmasing parpol atau orsospol peserta pemilihan umum. Calon terpilih untuk menjadi wakil rakyat duitenukan berdasarkan nomor urut calon yang disusun guna mewakili orsospol pada masingmasing daerah. Inilah yang disebut perhitungan suara secara proporsional, bukan menurut distrik pemilihan (yang pada setiap distrik hanya aka nada satu calon yang terpilih).

1) Keuntungan sistem proporsional

Dianggap lebih representative karena persentase perolehan suara setiap partai sesuai dengan persentase perolehan kursinya di parlemen. Tidak ada distorsi antara perolehan suara dan perolehan kursi. Setiap suara dihitung dan tidak ada yang hilang. Partai kecil dan golongan minoritas diberi kesempatan untuk menempatkan wakilnya di parlemen. Karena itu masyarakat yang heterogen dan pluralis lebih tertarik pada system ini.

\section{2) Kelemahan}

Kurang mendorong partai-partai yang berintegrasi satu sama lain, malah sebaliknya cenderung mempertajam perbedaan-perbedaan diantara mereka. Bertambahnya jumlah partai dapat menghambat proses integrasi diantara berbagai golongan di masyarakat yang sifatnya pluralis. Hal ini mempermudah fragmenrasi dan berdirinya partai baru yang pluralis.

Wakil rakyat kurang erat hubungannya dengan konstituennya, tetapi lebih erat dengan partainya (termasuk dalam hal akuntabilitas). Peranan partai lebih menonjol daripada kepribadian seorang wakil rakyat. Akibatnya, system ini member kedudukan kuat kepada pimpinan partai untuk menentukan wakilnya di parlemen melaluin Stelsel daftar (List System).

Banyaknya partai yang bersaing mempersukar satu partai untuk mencapai mayoritas di parlemen. Dalam system pemerintahan parlementer, hal ini mempersulit terbentuknya pemerintahan yang stabil karena harus mendasarkan diri pada koalisi.

\section{Asas-asas Pemilihan Umum}

Meskipun Undang-Undang Politik tentang Pemilihan Umum (UU Pemilu) dari Pemilu ke Pemilu beberapa kali mengalami perubahan, perubahan itu ternyata tidak bersifat mendasar. Secara umum, asas-asas dari Pemilu ke Pemilu di Indonesia dapat digambarkan sebagai berikut. 
a) Langsung, yaitu rakyat sebagai pemilih mempunyai hak untuk memberikan suaranya secara langsung, sesuai dengan kehendak hati nuraninya, tanpa perantara.

b) Umum, yaitu pada dasarnya semua warga negara yang memenuhi persyaratan sesuai dengan undang-undang berhak mengikuti Pemilu. Pemilihan yang bersifat umum menjamin kesempatan yang berlaku menyeluruh bagi semua warga negara, tanpa diskriminasi berdasarkan suku, agama, ras, golongan, jenis kelamin, kedaerahan, pekerjaan dan status sosial.

c) Bebas, yaitu setiap warga negara yang berhak memilih bebas menentukan pilihannya tanpa tekanan dan paksaan dari pihak manapun. Di dalam melaksanakan haknya, setiap warga negara dijamin keamanannya, sehingga dapat memilih sesuai kehendak hati nuarani dan kepentingannya. d) Rahasia, yaitu dalam memberikan suaranya, pemilih dijamin bahwa pilihannya tidak akan diketahui oleh pihak manapun dan dengan jalan apapun. Pemilih memberikan suaranya pada surat suara tanpa dapat diketahui oleh orang lain kepada siapa pun suaranya diberikan.

e) Jujur, yaitu setiap penyelenggara Pemilu, aparat pemerintah, peserta Pemilu, pengawas Pemilu, pemantau Pemilu, pemilih, serta semua pihak yang terkait harus bersikap dan bertindak jujur sesuai dengan peraturan perundang-undangan.

f) Adil, yaitu setiap pemilih dan peserta Pemilu mendapat perlakuan yang sama, serta bebas dari kecurangan pihak mana pun.

\section{PENUTUP}

Di kebanyakan negara demokrasi, pemilu dianggap sebagai lambang dan tolak ukur demokrasi. Pemilu yang terbuka, bebas berpendapat dan bebas berserikat mencerminkan demokrasi walaupun tidak beguitu akurat. Pemilihan umum ialah suatu proses pemilihan orangorang untuk mengisi jabatan-jabatan politik tertentu. Dalam ilmu politik dikenal berbagai macam sistem pemilu dengan berbagai variasi, tetapi umumnya berkisdar pada dua prinsip pokok, yaitu : sistem distrik dan sistem proprosional. Sejak awal kemerdekaan Indonesia telah mengalami pasang surut dalam sistem pemilu. Dari pemilu terdahulu hingga sekarang dapat diketahui bahwa adanya upaya untuk mencari sistem pemilihan umum yang cocok untuk Indonesia . sejak awal pemerintahan yaitu demokrasi parlementer, terpimpin, pancasila dan reformasi, dalam kurun waktu itulah Indonesia telah banyak mengalami transformasi politik dan sistem pemilu. Melihat 
fenomena politik Indonesia, sistem pemilihan umum proprosinal tertutup memang lebih menguntungkan, tetapi harus diikuti dengan transparansi terhadap publik kalau tidak akan menimbulkan oligarki pemerintahan.Pada akhirnya konsilidasi partai politik dan sistem pemilihan umum sudsah berjalan denganm baik. Akan tetapi, itu belum berarti kehidupan kepartaian Indonesia juga sudah benar-benar siap untuk memasuki zaman global. Sejumlah kelemahan yang bisa diinventarisir dari kepartaian kita adalah rekrutmen politik, kemandirian secara pendanaan, kohesivitas internal,dan kepemimpinan.

\section{DAFTAR PUSTAKA}

Darmini Roza dan Laurensius Arliman S Peran Pemerintah Daerah Di Dalam Melindungi Hak Anak Di Indonesia, Masalah-Masalah Hukum, Volume 47, Nomor 1, 2018.

Laurensius Arliman S, Komnas HAM dan Perlindungan Anak Pelaku Tindak Pidana, Deepublish, Yogyakarta, 2015.

Laurensius Arliman S, Penguatan Perlindungan Anak Dari Tindakan Human Trafficking Di Daerah Perbatasan Indonesia, Jurnal Selat, Volume 4, Nomor 1, 2016.

Laurensius Arliman S, Problematika Dan Solusi Pemenuhan Perlindungan Hak Anak Sebagai Tersangka Tindak Pidana Di Satlantas Polresta Pariaman, Justicia Islamica, Volume 13, Nomor 2, 2016.

Laurensius Arliman S, Pelaksanaan Perlindungan Anak Yang Tereksploitasi Secara Ekonomi Oleh Pemerintah Kota Padang, Veritas et Justitia, Volume 2, Nomor 1, 2016.

Laurensius Arliman S, Kedudukan Ketetapan MPR Dalam Hierarki Peraturan PerundangUndangan Di Indonesia, Lex Jurnalica, Volume 13, Nomor 3, 2016.

Laurensius Arliman S, Komnas Perempuan Sebagai State Auxialiary Bodies Dalam Penegakan Ham Perempuan Indonesia, Justicia Islamica, Volume 14, Nomor 2, 2017.

Laurensius Arliman S, Peranan Pers Untuk Mewujudkan Perlindungan Anak Berkelanjutan Di Indonesia, Jurnal Ilmu Hukum Tambun Bungai, Volume 2, Nomor 2, 2017.

Laurensius Arliman S, Mewujudkan Penegakan Hukum Yang Baik Untuk Mewujudkan Indonesia Sebagai Negara Hukum, Jurnal Hukum Doctrinal, Volume 2, Nomor 2, 2017. 
Laurensius Arliman S, Participation Non-Governmental Organization In Protecting Child Rights In The Area Of Social Conflict, The 1st Ushuluddin and Islamic Thought International Conference (Usicon), Volume 1, 2017.

Laurensius Arliman S, Partisipasi Masyarakat Dalam Pembentukan Perundang-Undangan Untuk Mewujudkan Negara Kesejahteraan Indonesia, Jurnal Politik Pemerintahan Dharma Praja, Volume 10, Nomor 1, 2017, https://doi.org/10.33701/jppdp.v10i1.379.

Laurensius Arliman S, Peran Komisi Perlindungan Anak Indonesia Untuk Mewujudkan Perlindungan Anak, Jurnal Respublica Volume 17, Nomor 2, 2018.

Laurensius Arliman S, Menjerat Pelaku Penyuruh Pengrusakan Barang Milik Orang Lain Dengan Mempertimbangkan Asas Fungsi Sosial, Jurnal Gagasan Hukum, Volume 1, Nomor 1, 2019.

Laurensius Arliman S, Ilmu Perundang-Undangan Yang Baik Untuk Negara Indonesia, Deepublish, Yogyakarta, 2019.

Laurensius Arliman S, Isdal Veri, Gustiwarni, Elfitrayenti, Ade Sakurawati, Yasri, Pengaruh Karakteristik Individu, Perlindungan Hak Perempuan Terhadap Kualitas Pelayanan Komnas Perempuan Dengan Kompetensi Sumber Daya Manusia Sebagai Variabel Mediasi, Jurnal Menara Ekonomi: Penelitian dan Kajian Ilmiah Bidang Ekonomi, Volume 6, Nomor 2, 2020.

Laurensius Arliman S, Pendidikan Kewarganegaraan, Deepublish, Yogyakarta, 2020.

Laurensius Arliman S, Makna Keuangan Negara Dalam Pasal Pasal 23 E Undang-Undang Dasar 1945, Jurnal Lex Librum, Volume 6, Nomor 2 Juni 2020, http://dx.doi.org/10.46839/1ljih.v6i2.151.

Laurensius Arliman S, Kedudukan Lembaga Negara Independen Di Indonesia Untuk Mencapai Tujuan Negara Hukum, Kertha Semaya Journal Ilmu Hukum, Volume 8, Nomor 7, 2020.

Laurensius Arliman S, Pelaksanaan Assesment Oleh Polres Kepulauan Mentawai Sebagai Bentuk Pelaksanaan Rehabilitasi Bagi Pecandu Dan Korban Penyalahgunaan Narkotika, Jurnal Muhakkamah, Volume 5, Nomor 1, 2020.

Laurensius Arliman S, Aswandi Aswandi, Firgi Nurdiansyah, Laxmy Defilah, Nova Sari Yudistia, Ni Putu Eka, Viona Putri, Zakia Zakia, Ernita Arief, Prinsip, Mekanisme Dan Bentuk Pelayanan Informasi Kepada Publik Oleh Direktorat Jenderal Pajak, Volume 17, No Nomor, 2020.

Larensius Arliman S, Koordinasi PT. Pegadaian (Persero) Dengan Direktorat Reserse Narkoba Polda Sumbar Dalam Penimbangan Barang Bukti Penyalahgunaan Narkotika, UIR Law Review, Volume 4, Nomor 2, 2020, https://doi.org/10.25299/uirlrev.2020.vol4(1).3779. 
Laurensius Arliman S, Tantangan Pendidikan Kewarganegaraan Pada Revolusi 4.0, Ensiklopedia Sosial Review, Volume 2, Nomor 3, 2020.

Muhammad Afif dan Laurensius Arliman S, Protection Of Children's Rights Of The Islamic And Constitutional Law Perspective Of The Republic Of Indonesia, Proceeding: Internasional Conference On Humanity, Law And Sharia (Ichlash), Volume 1, Nomor 2, 2020.

Otong Rosadi danLaurensius Arliman S, Urgensi Pengaturan Badan Pembinaan Idelogi Pancasila Berdasarkan Undang-Undang Sebagai State Auxiliary Bodies yang Merawat Pancasila dalam Perspektif Hak Asasi Manusia, Prosiding Konferensi Nasional Hak Asasi Manusia, Kebudayaan dan Tujuan Pembangunan Berkelanjutan Indonesia pada Masa Pandemi Covid-19: Tantangan untuk Keilmuan Hukum dan Sosial Volume 1, Universitas Pancasila, Jakarta, 2020. 